\title{
The Effect of Electrical Conductivity of Irrigation Water on Water Uptake by Capsicum in Soilless Media
}

\author{
S. Ahirwar* and M. Hasan \\ Department of Agricultural Engineering, Indian Agricultural Research Institute, \\ New Delhi-110012, India \\ *Corresponding author
}

\section{A B S T R A C T}

Keywords

Soilless media,

Capsicum,

Fertigation, Water

uptake

Article Info

Accepted:

17 November 2018

Available Online:

10 December 2018
The experiment was conducted during the year of 2015-2016 under semi-climate greenhouse condition at Center for Protected Cultivation Technology (CPCT), farm at Indian Agricultural Research Institute (IARI), New Delhi, to study the effect of electrical conductivity of irrigation water on crop water uptake. The yellow colored popular and widely accepted capsicum variety Swarna was selected for the study. Four strategies/treatments based on electrical conductivity of the fertigation solution were applied with three replications during the entire growing period. The maximum water uptake was observed for fifteen plants are $246 \mathrm{~kg}$ and minimum $17.85 \mathrm{~kg}$ during Fruiting and Vegetative stage respectively corresponding to EC 2.8 and $2.7 \mathrm{dS} / \mathrm{m}$ for their respective stage.

\section{Introduction}

The demand for fruits, vegetables and other horticultural crops has been rising continuously in the $21^{\text {st }}$ century. The vegetable sector has been growing rapidly to meet the rising demand of ever increasing population in order to ensure balanced diet to each and every person. On the other hand, the decreasing land holding of farmers has put lots of pressure to grow more from the limited cultivated area. Recent advancement in science and technology has provided scientific and advanced methods of cultivation, related cultural practices and input management techniques all over the world. The time has come to go beyond the boundaries of tradition way of cultivation and adopt such proven developed and advanced techniques. Protected cultivation, drip and sprinkler irrigation, offseason vegetables production, container and terrace gardening, green house technologies, soilless cultivation technologies have been found as proven advanced scientific techniques to increase the production, quality and productivity of horticultural crops in general and particularly for vegetables.

Protected cultivation technology has been continuously expanding on a commercial scale 
in more than 55 countries throughout the world (Nair and Barche, 2014). The development and rapid expansion of greenhouse technology in China has been faster than in any other country in the world (Shakuntala Pandey and Anil Pandey, 2015). The total protected cultivation area in India is approximately 50,000 ha (Hasan, 2015). The main purpose of protected cultivation is to facilitate suitable environment during the plant growth period so as to realize its maximum yield potential even in adverse climatic conditions (Nair and Barche, 2014). The major limitation of protected cultivation is various type of soil borne diseases (Fulya BaysalGurel et al., 2012). Solar heat or soil solarization, leaching, chemicals are some possible control measures of soil borne pathogens (Nereu Augusto Streck et al., 1994) but they are not effective and permanent solution. The chemical methods of soil disinfestation are costly and hazardous and it requires trained personnel and special equipment. In the above scenario, soilless cultivation is the possible alternative solution for sustaining protected cultivation.

Soilless cultivation is a practice of growing plants in soilless media which provide the facilities to reduce the soil related problems experienced in conventional crop cultivation (Aatif Hussain et al., 2014). Suitable soilless substrates have been found to be useful and effective for high quality horticultural crop production in protected structures (Murumkar A. R. et al., 2013). Soilless culture directly affects the development and maintenance of the extensive functional rooting system of the plants. A well growing substrate would provide sufficient anchorage to the plant, serves as reservoir for nutrients and water, allow oxygen diffusion to the roots and permit gaseous exchange between the roots and atmosphere outside the root substrate (Abad $e t$ al., 2002). One of the widely available soilless materials in the India is coconut coir dust also known as cocopeat. Cocopeat is an ecofriendly growing medium obtained after the extraction of coir fiber from the coconut husk. Cocopeat is $100 \%$ organic substance and is free from any harmful substance. It is considered as a good and effective growing soilless media with acceptable $\mathrm{pH}$, electrical conductivity and other chemical attributes (Awang et al., 2009).

Capsicum (Capsicum annuum L. var. grossum Sendt) is also known as bell pepper or sweet pepper and is one of the most popular and highly remunerative annual herbaceous vegetable crops particularly for protected cultivation. It is a very rich source of vitamins $\mathrm{A}$ and $\mathrm{C}$ (ascorbic acid). It has been found that every 100 gram of edible portion of capsicum provides $24 \mathrm{kcal}$ of energy, 1.3 gram of protein, 4.3 gram of carbohydrate and 0.3 gram of fat (Anon., 1997). The main chemical content in sweet pepper is Capsaicin. It has attained a status of high value crop in India in the recent years and occupies a pride place among vegetables in Indian cuisine, because of its delicate taste and pleasant flavour coupled with rich content of ascorbic acid and other vitamins and minerals. Sweet pepper consumption in India is increasing now-a day due to increasing demand by urban consumers and export sector. The export market needs fruits with longer shelf life, medium size, tetra lobed fruits with an attractive dark colour, mild pungency and good taste. Such fruit can be grown mainly in protected cultivation with soilless media.

Water and nutrient management through drip fertigation in soilless media improves water, nutrient and air distribution in the growing medium and subsequently improves crop health and productivity. Drip fertigation in soilless cultivation is used to supply complete nutrient solution with irrigation water. Fertigation scheduling is the process of determining how much water and nutrient 
solution to apply by fertigation volume and timing. The main goal of water and nutrient management for greenhouse soilless crops is to enhance crop growth and product quality and simultaneously reduce losses of water and nutrients to the environment. Precise amount of water and nutrients as per crop demand in different stages through drip fertigation is important to reach this goal. In order to do so, quantitative information on demand and uptake of water and nutrients and related information on crop behavior is required. Such information needs to be generated through controlled experiments inside greenhouse with soilless media. The electrical conductivity (EC), amount and frequency of fertigation (irrigation with nutrient solution) are the most necessary variables to control the supply of water and nutrients to the crops (Martine Dorai et al., 2001).

\section{Materials and Methods}

Experimental site, plant and growth condition

The experiment was carried out in the semi climate controlled greenhouse of Centre for Protected Cultivation Technology (CPCT) farm in Indian Agricultural Research Institute (IARI), New Delhi (IARI is situated in west Delhi between latitude 28038'23' $\mathrm{N}$ and longitude 77009'27"E with an altitude of 228.61m above mean sea level), in 2015-16. The greenhouse experiment was laid in a complete randomized design with four treatments and three replications for each growing stage such as vegetative stage (1-52 DAT), flowering stage (53-133DAT) and fruiting stage (134-190) of the capsicum crop. Capsicum seeds were sown in mixture of cocopeat, vermiculite and perlite $(3: 1: 1)$ in the trays (345 cells/tray). The seedlings were raised in modern nursery and watered twice a daily. At 30 days (when the seedlings were about $2 \mathrm{~cm}$ in height with 3-4 leaves), the plants were transplanted in cocopeat grow bag. In a cocopeat growbag three plants were placed at $30 \mathrm{~cm}$ distance. Greenhouse capsicum cultivars generally have an indeterminate pattern of growth. Because the plants can grow up to $150 \mathrm{~cm}$ tall during a growing season of 250 days, they need to be support vertically. The stems were clipped with the strings plastic clips. Regular training, pruning and trellising was done without damage to the crop (Singh and Kumar, 2004).

\section{Electrical conductivity of the solution and irrigation}

Capsicum is very susceptible to water stress condition and highly affected by electrical conductivity of the irrigation water. In soilless cultivation fertilizers are added to the irrigation water that increases the electrical conductivity of the solution and media. Four strategies/treatments based on electrical conductivity of the fertigation solution were applied with three replications during the entire growing period. Treatments were taken as $(2.4,2.6,2.8),(2.3,2.5,3.0),(2.7,3.0,3.2)$ and $(2.5,2.5,2.5) \mathrm{dS} / \mathrm{m}$ respectively for vegetative, flowering and fruiting stages.

\section{Measurements and calculations}

Physical and chemical properties (measured using instruments given in Table 1) of the cocopeat as soilless media are calculated by the standard procedure given in table 2. The irrigation water was applied to the experimental plots through drip irrigation method with the help of TDR. The volume of water applied was estimated based on pan evaporation, pan coefficient, crop coefficient of the sweet pepper, cropped area, percentage wetted area and application efficiency of the drip system. Also the value of coefficient (factor) of evapotranspiration under greenhouse was considered as 0.45 (Hasan et al., 2010) in the estimation of irrigation requirement. 
Actual evapotranspiration (ETc) under greenhouse with drip irrigation system was estimated as follows

$\mathrm{ETo}=\mathrm{Kp} * \mathrm{Epan}$

Where,

ETo $=$ Reference crop evapotranpiration, $\mathrm{mm}$ Epan $=$ Pan evaporation, mm day $^{-1}$

$\mathrm{Kp}=$ Pan coefficient $=0.8 ;($ FAO $56-$ Allen et al., 1998)

$\mathrm{ETc}=\mathrm{ETo}^{*} \mathrm{Kc}$

Where, ETc = Actual evapotranspiration, $\mathrm{mm}$

Kc values for sweet pepper during the growing season was considered as follows (FAO 56 - Allen et al., 1998)

Initial stage $=\mathrm{Kc}$ value of 0.6 for the duration 30 days

Development stage $=\mathrm{Kc}$ value of 0.9 for the duration 40 days (considered average of initial and mid stage)

Mid stage $=\mathrm{Kc}$ value of 1.15 for the duration 140 days

Late stage $=\mathrm{Kc}$ value of 0.9 for the duration 30 days

Greenhouse coefficient (Gc) for evapotranspiration was 0.45

Ideal percentage of wetted area (Wa) at maximum limit was considered for drip irrigation as $67 \%$; approx 0.7. (Keller and Bliesner, 1990)

The application efficiency was considered 90 $\%$ according to the past experience from the drip irrigation system which was taken on to the field experiment. By considering the above mentioned factors, to estimate the volume of water to be applied, ETc was estimated and multiplied by the cropped area. The pan data was available online at IARI web site.

Hence, $\mathrm{ETc}=$ Epan $\mathrm{x}$ Kp x Kc x Wa x Gc.

Water requirement for sweet pepper crop under drip irrigated greenhouse

$=($ Epan $x \mathrm{Kp}$ x Kc x Wa x Gc) / Application efficiency, mm (Majumdar, 2004)

$=(($ Epan x Kp x Kc x Wa x Gc) / Application efficiency) $x$ Cropped Area $\left(\mathrm{m}^{2}\right)$, liters

Initial irrigation was estimated by using the soilless information as follows

Field capacity $(\mathrm{FC})=42.2 \%$ (volumetric $)$

Permanent wilting point $(\mathrm{PWP})=18.2 \%$ (volumetric)

Available water $=\mathrm{FC}-\mathrm{PWP}=24 \%$ (volumetric)

Water requirement up to $50 \mathrm{~mm}$ effective root zone depth in soilless cocopeat grow bag

$=24 / 100 \times 50 \mathrm{~mm} \times 100 \mathrm{~m}^{2}$ x $0.2=240$ liters (effective cropped area $=0.2$ )

Water requirement of the capsicum crop and the irrigation applied are similar as there was no rainfall contribution to the field under the greenhouse.

The statistical analysis of data of each parameter was done by the statistical method known as "Analysis of Variance" appropriate for complete randomized design. The coefficient of variance (CV) was worked out. Where the results were significant, the least significant difference (LSD) at 5\% level of significance was estimated. The statistical software of SPSS was used for the analysis. 


\section{Results and Discussion}

Physical and chemical properties of cocopeat soilless media

The following important physical and chemical properties of cocopeat soilless media were determined as per the standard procedure (i.e. mentioned in earlier section) and presented in tabular form.

The $\mathrm{pH}$ and $\mathrm{EC}$ value showed that cocopeat media was acidic and slightly saline in nature. Its porosity was very high and the low values of available $\mathrm{N}, \mathrm{P}$ and $\mathrm{K}$ showed that it was inert in nature. The above physical and chemical properties are required for irrigation and fertigation management in cocopeat soilless media.

Moisture retention curve for cocopeat soilless media

The moisture characteristic curve represents the volumetric water content and suction relation in one graph. From the above graph it is obvious that the higher the suction the less the soilless media water is available for the plant (Fig. 1).

Experiment has shown that cocopeat media water at a suction 15 bar cannot be taken up by plants and wilting occurs. This point is called "permanent wilting point". This the lower limit of amount of available water for plant growth. Also an upper limit exist suction $1 / 3$ bar and this point is known as field capacity.

The regression equation was developed $(\mathrm{Y}=$ $7.2 \ln (\mathrm{X})+36.74)$ with regression coefficient of 0.981 . The volumetric water content was estimated as $42.20 \%$ at $18.20 \%$ at $1 / 3$ bar and 15 bar respectively. It represented the field capacity and wilting point respectively of the soilless media. The volumetric water content at higher suction values and at ultimate wilting point (31 bar) can be estimated from the graph assuming the asymptotic behavior of the graph.

\section{Effect of electrical conductivity on water uptake among the different treatments}

Effect of electrical conductivity on the water uptake at different stages of the growing period

\section{a) For vegetative stage}

Crop water uptake during entire vegetative stage (52 days) was found to be maximum 30 $\mathrm{kg}$ and minimum $17.85 \mathrm{~kg}$ corresponding to EC 2.4 and $2.7 \mathrm{dS} / \mathrm{m}$ as per the treatments $\mathrm{T} 1$ and $\mathrm{T}_{3}$ respectively for 15 plants (Fig. 2).

Higher the EC reduces the water uptake by plants due the reverse osmosis and too low a concentration causes mineral deficiency and restricts plant growth (Winsor and Adams, 1987). In this stage data showed the significant difference $(P \leq 0.05)$ generally in favour Treatment 1 (EC $2.4 \mathrm{dS} / \mathrm{m})$ and Treatment 2 (EC $2.3 \mathrm{dS} / \mathrm{m})$.

\section{b) For flowering stage}

Crop water uptake during entire Flowering stage was found to be maximum $52.5 \mathrm{~kg}$ and minimum $36 \mathrm{~kg}$ corresponding to EC 2.6 and $3.0 \mathrm{dS} / \mathrm{m}$ as per the treatments $\mathrm{T}_{1}$ and $\mathrm{T}_{3}$ respectively for 15 plants). Treatment 1 (52.5 $\mathrm{kg})$ exhibited greater $(P \leq 0.05)$ uptake water over Treatment 4 (control, $41.25 \mathrm{~kg}$ ). This was followed by Treatment $2(47.25 \mathrm{~kg})$ having significantly greater $(P \leq 0.05)$ water uptake over the control (Treatment 4) (Fig. 3).

\section{c) For fruiting stage}

Increasing electrical conductivity of the irrigation water reduces the water uptake by 
the capsicum plants. Treatment $T_{3}$ having greater electrical conductivity compare to the other treatments. Crop water uptake during entire fruiting stage (98 days, including harvesting stage) was found to be maximum $246 \mathrm{~kg}$ and minimum $209.7 \mathrm{~kg}$ corresponding to EC 2.8 and $3.2 \mathrm{dS} / \mathrm{m}$ as per the treatments $\mathrm{T}_{1}$ and $\mathrm{T}_{3}$ respectively for 15 plants (Fig. 4). Figure 4 shows the Treatment $\mathrm{T}_{3}(209.7 \mathrm{~kg})$ registered significantly different $(P \leq 0.05)$ from the other treatments. Water uptake by the plants did not show any significant difference among Treatment $\mathrm{T}_{1}(246 \mathrm{~kg})$, Treatment $\mathrm{T}_{2}$ $(234.45 \mathrm{~kg})$ and treatment $\mathrm{T}_{4}(221.25 \mathrm{~kg})$.

\section{d) Water uptake entire the growing period}

Crop water uptake during entire growing period was found to be maximum $328.50 \mathrm{~kg}$ and minimum $263.55 \mathrm{~kg}$ corresponding to the treatments $T_{1}$ and $T_{3}$ respectively for 15 plants. Selection of the EC for the plant requirement is very necessary. (Bruggink et al., 1987) proposed that it should be possible to enhance plant growth by adapting the EC level to the rate of transpiration. Adequate EC provide the good transpiration (Fig. 5).

\section{Yield of capsicum}

Capsicum colored fruit total yield from three harvesting and average yield of the three replications were found to be maximum 41.15 $\mathrm{kg}$ (in which applied solution EC was 2.4 $\mathrm{dS} / \mathrm{m}$ for vegetative stage, $2.6 \mathrm{dS} / \mathrm{m}$ for flowering stage and $2.8 \mathrm{dS} / \mathrm{m}$ for fruiting stage) and minimum $20.05 \mathrm{~kg}$ (in which applied solution EC was $2.7 \mathrm{dS} / \mathrm{m}$ for vegetative stage, $3 \mathrm{dS} / \mathrm{m}$ for flowering stage and $3.2 \mathrm{dS} / \mathrm{m}$ for fruiting stage) from the treatments $T_{1}$ and $T_{3}$ each having 15 plants respectively (Fig. 6).

Table.1 Physical and chemical properties of soilless cocopeat media

\begin{tabular}{|l|l|}
\hline Parameters & Instrument used (Methods) \\
\hline Air filled porosity & Saturation and Drainage method \\
\hline Bulk density & Gravimetric method \\
\hline Field capacity & Pressure plate apparatus (Richard and Weaver, 1944) \\
\hline Permanent wilting point & Pressure plate apparatus (Richard and Weaver, 1944) \\
\hline Available nitrogen & Kjeldhal apparatus (Subbiah et al., 1956) \\
\hline Available potassium & Flame photometer (Hanway et al., 1952) \\
\hline Available phosphorous & Spectrophotometer (Olsen et al., 1954) \\
\hline
\end{tabular}

Table.2 Physical and chemical properties of cocopeat soilless media

\begin{tabular}{|l|c|}
\hline \multicolumn{1}{|c|}{ Parameters } & Values \\
\hline Air filled porosity (\%) & 30 \\
\hline Total Porosity (\%) & 90 \\
\hline Bulk density (g/cc) & 0.1 \\
\hline Field capacity (\% V/V) & 42.2 \\
\hline Permanent wilting point (\% V/V) & 18.2 \\
\hline Available nitrogen (mg/l) & 0.2 \\
\hline Available potassium(mg/l) & 0.1 \\
\hline Available phosphorous (mg/l) & 0.2 \\
\hline pH & 5.6 \\
\hline EC (dS/m) & 0.7 \\
\hline
\end{tabular}


Int.J.Curr.Microbiol.App.Sci (2018) 7(12): $2307-2319$

Table.3 Yield variation of capsicum during growing period

\begin{tabular}{|c|c|c|c|c|c|c|c|c|c|c|c|}
\hline \multirow{3}{*}{$\begin{array}{l}\text { No. of } \\
\text { treatment }\end{array}$} & \multirow[t]{3}{*}{$\mathrm{EC}$ in $\mathrm{dS} / \mathrm{m}$} & \multicolumn{3}{|c|}{ R1 } & \multicolumn{3}{|c|}{ R2 } & \multicolumn{3}{|c|}{ R3 } & \multirow{3}{*}{$\begin{array}{l}\text { Yield in } \\
\mathrm{kg}\end{array}$} \\
\hline & & $\begin{array}{c}\text { 1st } \\
\text { harvest }\end{array}$ & $\begin{array}{c}\text { 2nd } \\
\text { harvest }\end{array}$ & $\begin{array}{c}\text { 3rd } \\
\text { harvest }\end{array}$ & $\begin{array}{c}\text { 1st } \\
\text { harvest }\end{array}$ & $\begin{array}{c}\text { 2nd } \\
\text { harvest }\end{array}$ & $\begin{array}{c}\text { 3rd } \\
\text { harvest }\end{array}$ & $\begin{array}{c}\text { 1st } \\
\text { harvest }\end{array}$ & $\begin{array}{c}\text { 2nd } \\
\text { harvest }\end{array}$ & $\begin{array}{c}\text { 3rd } \\
\text { harvest }\end{array}$ & \\
\hline & & $27 / 2 / 2016$ & $16 / 3 / 2016$ & $14 / 4 / 2016$ & $27 / 2 / 2016$ & $16 / 3 / 2016$ & $14 / 4 / 2016$ & $27 / 2 / 2016$ & $16 / 3 / 2016$ & $14 / 4 / 2016$ & \\
\hline T1 & $2.4,2.6,2.8$ & 13.4 & 14.6 & 10.4 & 14.15 & 16.75 & 12.45 & 14 & 15 & 12.7 & 41.15 \\
\hline $\mathbf{T} 2$ & $2.3,2.5,3$ & 12.89 & 13.73 & 10.58 & 13.68 & 15.74 & 10.57 & 9.8 & 12.9 & 9.1 & 36.3 \\
\hline T3 & $2.7,3,3.2$ & 4.06 & 7.43 & 7.7 & 5.8 & 7.3 & 6.7 & 6.2 & 8.6 & 6.8 & 20.05 \\
\hline $\mathbf{T 4}$ & $2.5,2.5,2.5$ & 9.87 & 8.86 & 9.61 & 12 & 12 & 9 & 10.3 & 11.6 & 7.8 & 28.34 \\
\hline Total & & & & & & & & & & & 125.84 \\
\hline
\end{tabular}


Table.4 Treatment wise crop water productivity and yield estimation for capsicum grown in soilless cultivation

\begin{tabular}{|l|l|l|l|}
\hline $\begin{array}{l}\text { Treat- } \\
\text { ment }\end{array}$ & $\begin{array}{l}\text { Yield } \\
\text { (kg) }\end{array}$ & $\begin{array}{l}\text { Irrigation } \\
\text { (cubic } \\
\text { meter) }\end{array}$ & $\begin{array}{l}\text { Crop Water } \\
\text { Productivity } \\
\left(\mathrm{kg} / \mathrm{m}^{3}\right)\end{array}$ \\
\hline T1 & 41.15 & 0.345 & 119.28 \\
\hline T2 & 36.3 & 0.330 & 110.00 \\
\hline T3 & 20.05 & 0.278 & 72.12 \\
\hline T4 & 28.34 & 0.316 & 89.68 \\
\hline
\end{tabular}

Fig.1 Moisture characteristic curve for cocopeat

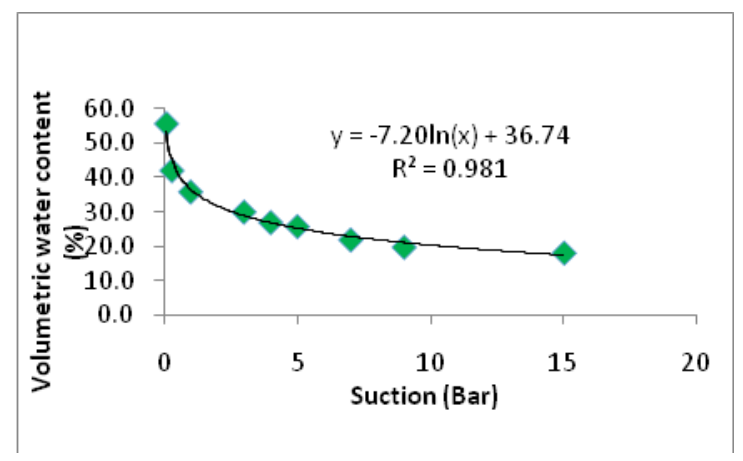

Fig.2 Water uptake by capsicum through different treatments in vegetative stage

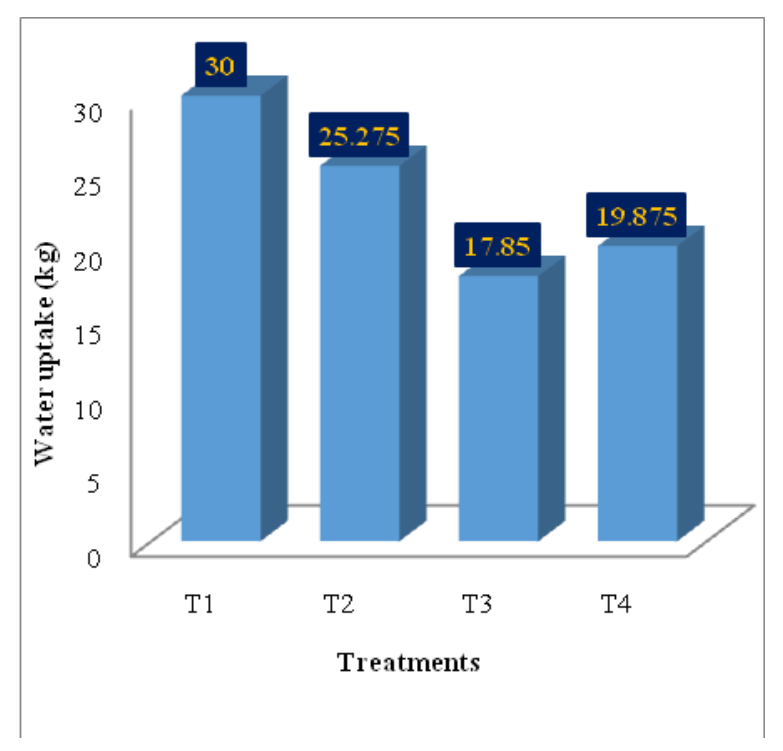


Fig.3 Water uptake by capsicum through each treatment in flowering stage

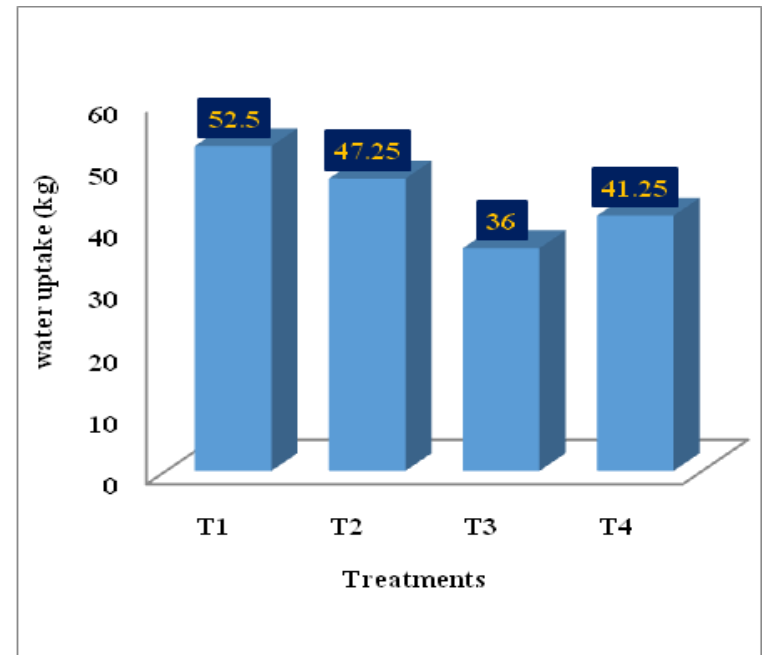

Fig.4 Water uptake by capsicum through each treatment in fruiting stage

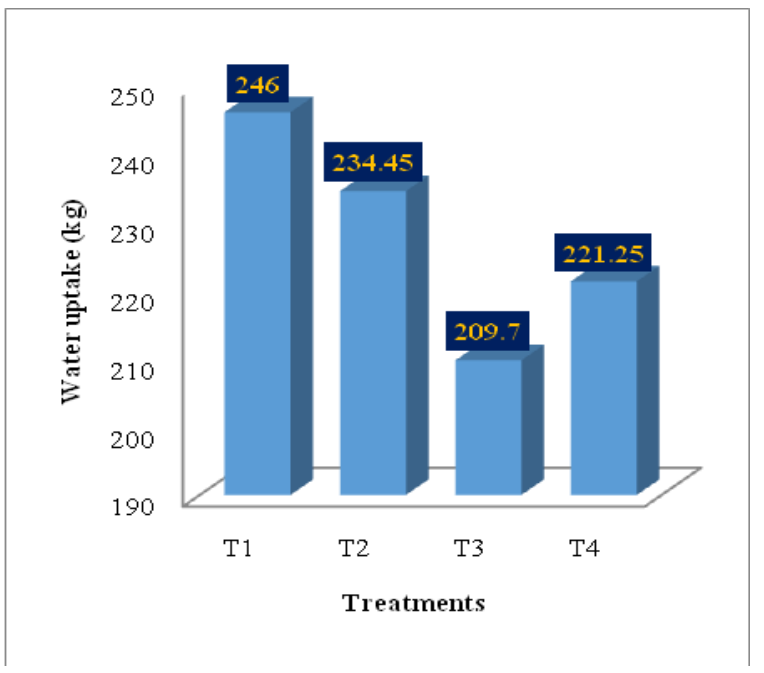

Fig.5 Water uptake by capsicum through each treatment during the entire growing period

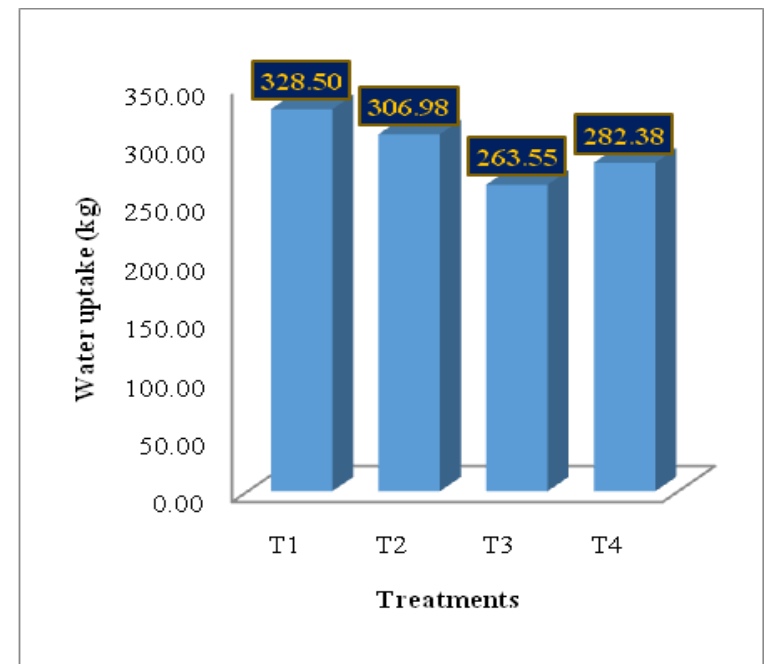


Fig.6 Yield of capsicum through each treatment

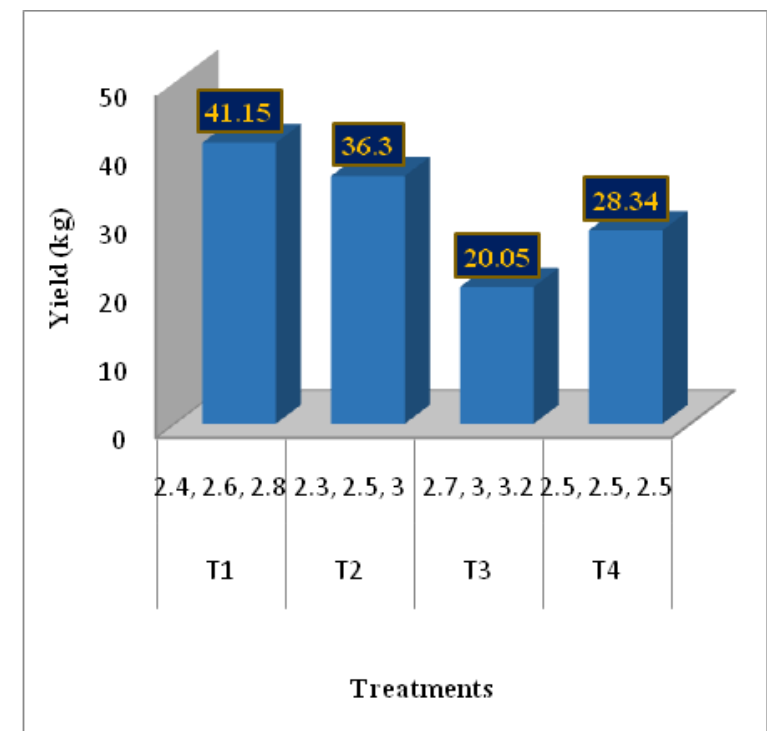

Fig.7 Relation between yield and crop water productivity

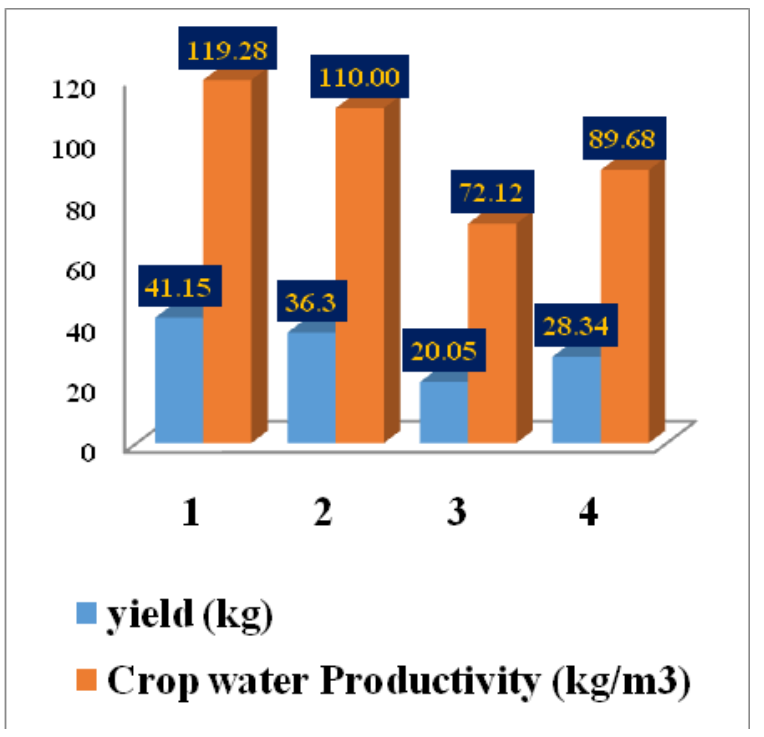

The large difference in yield was attributed to minor differences in fertigation EC during different crop stages. It showed the importance and sensitivity of fertigation EC (Fig. 7).

Yield of treatment $\mathrm{T} 1$ significantly increased $(P \leq 0.05)$ over the other treatments (Table 3 ). This was followed by treatment $\mathrm{T}_{2}$ which also registered significantly $(P \leq 0.05)$ higher yield over the treatment $\mathrm{T}_{3}$ and Treatment $\mathrm{T}_{4}$.

Crop water productivity was found to be maximum $119.28 \mathrm{~kg} / \mathrm{m}^{3}$ and minimum 72.12 $\mathrm{kg} / \mathrm{m}^{3}$ corresponding to the treatments $T_{1}$ and $\mathrm{T}_{3}$ respectively having 15 plants each. The corresponding yield was found to be maximum $41.15 \mathrm{~kg}$ and minimum $20.05 \mathrm{~kg}$ 
for the treatments $T_{1}$ and $T_{3}$ respectively. Crop water productivity was found to be very high for greenhouse capsicum grown in soilless media in comparison with soil due to the fact that ET was very low for soilless media grow bag (Table 4).

Summary and conclusion of the study are as follows

Water is the forerunner and sustainer of all life on the planet, especially the humankind. Use of soilless cultivation is one of the top priorities for conserving and utilizing the irrigation water judiciously. In soilless cultivation, cocopeat media having high water holding capacity causes poor air-water relationship, leading to low aeration within the medium and thus affecting the oxygen diffusion to the roots.

Application of adequate amount of water as per the plant requirement is very necessary for plant growth and production of high yield. Capsicum crop is found to be susceptible to water stress condition and electrical conductivity (EC) of the irrigation water. To overcome these problems, research was conducted in the research farm of Center for Protected Cultivation Technology (CPCT) in Indian Agricultural Research Institute, New Delhi, India during October 2015 to April 2016. Based on the results of this study the following conclusions were drawn.

Crop water uptake was found to be maximum $246 \mathrm{~kg}$ and minimum 17.85 during fruiting and vegetative stage respectively corresponding to EC 2.8 and $2.7 \mathrm{dS} / \mathrm{m}$ for entire crop duration. The maximum and minimum water consumption occurred during fruiting and vegetative stage respectively with minor difference in fertigation EC.

Capsicum colored fruit yield was found to be maximum $41.15 \mathrm{~kg}$ and minimum $20.05 \mathrm{~kg}$ corresponding to the treatments $T_{1}$ and $T_{3}$ respectively having 15 plant each. The large difference in yield was attributed to minor differences in fertigation EC during different crop stages. It showed the importance and sensitivity of fertigation EC.

Crop water productivity was found to be maximum $119.28 \mathrm{~kg} / \mathrm{m}^{3}$ and minimum 72.12 $\mathrm{kg} / \mathrm{m}^{3}$ corresponding to the treatments $T_{1}$ and $\mathrm{T}_{3}$ respectively having 15 plant each. Crop water productivity was found to be very high for greenhouse capsicum grown in soilless media in comparison with soil due to the fact that ET was very low for soilless media.

The best strategy for capsicum was treatment $\mathrm{T}_{1}$ in which the electrical conductivity of fertigation solution was maintained as 2.4, 2.6, $2.8 \mathrm{dS} / \mathrm{m}$ respectively for vegetative, flowering and fruiting stage.

\section{Acknowledgements}

We are grateful to Dr. I. M. Mishra, Dr. A. Sarangi and Dr. D. K. Singh for their insights and advice at various stages of this research.

\section{References}

Abad, M., Noguera, P., Puchades, R., Maquieira, A., and Noguera, V., (2002). Physico-chemical and chemical properties of some coconut coir dusts for use as a peat substitute for containerised ornamental plants. Bioresource Technology, 82(3): 241245.

Allen, R. G., Ereira, L.S., Raes, D. and Smith, M., (1998). Crop Evapotranspiration Guidelines for Computing Crop Water Requirement. FAO, Irrigation and Drainage Paper 56. Food and Agriculture Organization of the United Nations, Rome, Italy.

Anonymous (1997). Statistical data on 
Horticultural Crops in Karnataka. Government of Karnataka, Department of Horticulture, Lalbaugh, Bangalore, 813.

Awang, Y., Shaharom, A. S., Mohamad, R. B., and Selamat, A., (2009). Chemical and physical characteristics of cocopeatbased media mixtures and their effects on the growth and development of Celosia cristata. Am J Agric Biol Sci, 4: 63-71.

Baysal-Gurel, F., Gardener, B. M., and Miller, S. A., (2012). Soilborne Disease Management in Organic Vegetable Production. Organic Agriculture. Available on: www.extension.org/pages/64951.

[Accessed: February 28, 2016]

Bruggink G.T., Schouwink H.E., Coolen E.A.J.M., (1987). Effects of different day and night osmotic pressure of the nutrient solution on growth, water potentials and osmotic potentials of young tomato plants in soilless culture. Soilless Culture, 3 (2): 8-19

Dorai, M., Papadopoulos, A., and Gosselin, A., (2001). Influence of electric conductivity management on greenhouse tomato yield and fruit quality. Agronomie, 21(4): 367-383.

Hanway, J. J., and Heidel, H. (1952). Soil analysis methods as used in Iowa state college soil testing, laboratory. Iowa agriculture, 57: 1-31

Hasan M., (2015). "Protected Cultivation and Drip fertigation technology for sustainable food production" in the Souvenir "Second International conference on bio resource and stress management" during $7^{\text {th }}-10^{\text {th }}$ Jan, 2015 at Hyderabad.

Hasan M., Singh B., Singh M. C., Singh A. K., (2010). Fertigation scheduling for horticultural crops. Technical Bulletin No TB-ICN: 80/2010.

Hussain, A., Iqbal, K., Aziem, S., Mahato, P., and Negi. A. K., (2014). A Review on The Science of Growing Crops Without Soil (Soilless Culture) A Novel Alternative For Growing Crops. International Journal of Agriculture and Crop Sciences, 7(11): 833-842.

Keller, J. and Bliesner R. D., (1990). Sprinkler and trickle irrigation. AVI, Van Nostrand Reinhold, New York.

Majumdar D. K., (2004). Irrigation Water Management Principles and Practice. Prentice-Hall of India Pct. Limited. New Delhi.

Murumkar, A. R., Umesha, B., Palanisamy, D., Basu, S. S, and Durairaj, C. D., (2013). Effect of Growing Media on its Physical and Chemical Properties on Beet Root Yield under Protected Cultivation. Indian Journal of Agricultural Research, 47(2): 124-129.

Nair R and Barche S. (2014). Protected Cultivation of Vegetables- Present Status and Future Prospects in India. Indian Journal of Applied Research. Vol. 4(6): 245-247

Olsen, S. R., C. V. Cole, F. S. Watanabe and L. A. Dean, (1954). Estimation of available $\mathrm{P}$ in soils by extraction with sodium bicarbonate. Circular of the United States Department of Agriculture, 939, US Government Printing Office, Washington D.C.

Pandey, S., and Pandey, A., (2015). Greenhouse Technology. Social Issues and Environmental Problems, 3: 1-3.

Richards, L. A., and Weaver, L. R., (1944). Moisture retention by some irrigated soils as related to soil moisture tension. Journal agriculture. Research, 69(6): 215-235.

Singh, B. and Kumar, M., (2004). Performance of Sweet Pepper Varieties under Semi-Climate Controlled Greenhouse Conditions of Northern India. In International Symposium on Greenhouses, Environmental Controls 
and In-house Mechanization for Crop Production in the Tropics 710: 355-358.

Streck, N. A., Schneider, F. M., and Buriol, G. A., (1995). Effect of soil solarization on tomato inside plastic greenhouse. Ciência Rural, 25(1): 5-9.

Subbiah, B. V., and Asija, G. L., (1956). A rapid procedure for the estimation of available nitrogen in soils. Current science, 25(8): 259-260.

Winsor, G., and Adams, P. (1987). Glasshouse crops. Volume 3. Diagnosis of mineral disorders in plants. Her Majesty's Stationery Office.

\section{How to cite this article:}

Ahirwar, S and Hasan, M. 2018. The Effect of Electrical Conductivity of Irrigation Water on Water Uptake by Capsicum in Soilless Media. Int.J.Curr.Microbiol.App.Sci. 7(12): 2307-2319. doi: https://doi.org/10.20546/ijcmas.2018.712.262 